JABES

28,2

86

Received 27 December 2019 Revised 10 February 2020 30 June 2020

18 September 2020

Accepted 26 September 2020

\title{
Food risk in consumers' eye and their consumption responses: evidence from Hanoi survey
}

\author{
Thanh Mai Ha
}

Department of Agricultural Economics and Policies, Faculty of Economics and Rural Development, Vietnam National University of Agriculture, Ha Noi, Viet Nam, and Shamim Shakur and Kim Hang Pham Do School of Economics and Finance, Massey University, Palmerston North, New Zealand

\begin{abstract}
Purpose - This paper analyses Hanoi consumers' evaluation of food risk and response to the perceived risk. Design/methodology/approach - The authors employed the mixed method approach that integrates segmentation analysis on the survey data and information from group discussions.

Findings - Based on consumers' risk rating of six food groups and level of food safety worry, the authors identified four distinct consumer segments: low, moderate, high and very-high-risk perception. The authors found the existence of widespread food safety concerns among Hanoi consumers. Living in an urban region was associated with a higher level of food risk perception. Moderate, high and very-high-risk perception segments exhibited a very low level of institutional trust and subjective control over hazards. Response to the perceived risk differed across segments. "Very high-risk perception" was associated with the most risk-averse behaviour, putting more effort into seeking food safety information and engaging more in supermarket purchase. Consumers with a low and moderate perceived food risk participate more in self-supply of food to reduce their food safety concern. Practical implications - The paper provides empirical evidence on consumers' evaluation of food risk and their risk-reducing strategies to support the risk communication in Vietnam.

Social implications - Enhancing institutional trust and risk communication including hazard education can improve consumer confidence in food.
\end{abstract}

Originality/value - This is the first segmentation study on consumer food risk perception in Vietnam.

Keywords Food safety, Risk perception, Vegetables, Risk reduction strategies

Paper type Research paper

\section{Introduction}

The past two decades have witnessed a series of highly publicised food safety incidents worldwide. Examples include melamine-contaminated infant formula in China (2008), Dioxincontaminated chicken feed in Europe (2011-2012), horse meat scandal in England and Ireland (2013) (Premanandh, 2013) and plasticiser use in Taiwan food (2011) (Li and Ko, 2012). Major food-borne outbreaks occur not only in developing but also in developed countries (Yang et al., 2017). Food safety anxieties are considerably growing, particularly in the developed world. But it is the developing countries that are more affected by food-borne illness (WHO, 2015).

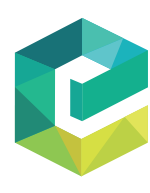

Journal of Asian Business and Economic Studies Vol. 28 No. 2,2021 pp. $86-100$ Emerald Publishing Limited 2515-964X

DOI 10.1108/JABES-12-2019-0126

\section{JEL Classification — C91, D12, Q10}

(C) Thanh Mai Ha, Shamim Shakur and Kim Hang Pham Do. Published in Journal of Asian Business and Economic Studies. Published by Emerald Publishing Limited. This article is published under the Creative Commons Attribution (CC BY 4.0) licence. Anyone may reproduce, distribute, translate and create derivative works of this article (for both commercial and non-commercial purposes), subject to full attribution to the original publication and authors. The full terms of this licence may be seen at http:// creativecommons.org/licences/by/4.0/legalcode.

The authors appreciate the support from the staff of Vietnam National University of Agriculture during the survey. They thank the reviewers for their invaluable comments on this paper.

Funding: This research did not receive any specific grant from funding agencies in the public, commercial or not-for-profit sectors. 
Food safety remains one of the biggest challenges in Vietnam. In this developing country, millions of small-scale farmers, processors and traders participate in complex food chains, but only limited resources are allocated for food safety surveillance. Foodborne outbreaks occur frequently. The microbiological pathogen is the leading cause, responsible for $33.2 \%$ of food poisoning cases. The corresponding figures for toxin and chemical contaminations are 25.2 and $10.4 \%$, respectively (Sarter et al., 2012). Food safety is undoubtedly a problem, but poor risk communication has heightened risk perception. Media have frequently expressed consumers' pessimistic feeling about food safety. In their eyes, unsafe food is the leading cause of increased cancer cases in recent years (Nguyen-Viet et al., 2017).

Consumers might be vulnerable from many aspects of food risk such as price volatility, food insecurity, nutrition insecurity and food unsafety. Among these aspects, this paper only focusses on the safety dimension. Consumer evaluation of food risk, or perception of food risk in this paper, is defined as their judgement of the health risk from consumption of food, in general. Prior studies found several psychological determinants of food risk perception. A heightened perceived risk from food is linked with negative emotional interpretations such as concerns or fears (Grunert, 2005). Trust in regulators and food industry reduces the perceived food risk, especially when consumer knowledge is insufficient (Siegrist, 2000). Risk characteristics of a hazard, for example, the extent to which the hazard is controllable, can shape public perception of the hazard (Slovic, 1987). The belief that all food hazards are dangerous and challenging to control leads to the view that food, as a whole, is risky to consume. In other words, perception at the hazard level influences risk perception at the product level (Ha et al., 2020).

Risk perception is a crucial driver of food choice behaviour (Yeung and Morris, 2006). Since most of the consumers are risk-averse, if the risk is perceived to be higher than the acceptable level, consumers will try to reduce the risk (Mitchell, 1999; Yeung and Morris, 2006). Their responses to the perceived risk include seeking food safety information (Yang et al., 2020), buying local, traceable food or growing their own food (Green et al., 2003). Other risk-reducing strategies are purchasing high-quality food, choosing a reputable place to purchase and selecting highly priced products (Yeung and Yee, 2002).

Segmentation of consumers based on food risk assessment and its related factors has gained popularity worldwide. Using risk perception of food hazards, food safety worry and subjective knowledge of food hazards, Liu et al. (2014) segmented Chinese consumers into three groups: worried and knowledgeable, worried and ignorant and moderately worried. In their study, Kennedy et al. (2008) employed five factors to classify US consumers. These factors are food safety concerns, trust, desire for a high level of regulation, acceptance for the number of people who are affected by food-borne illness and preference for the right to purchase unsafe foods. These authors then found five subgroups that are either "confident", "independent", "trusting", "cautious" or "apprehensive" consumers. Lacking from previous segmentation studies is the linkage between risk perception of food and risk-reducing behaviour. Though many attempts have been made to investigate food safety risk perception in Vietnam (Figuié et al., 2004; Wertheim-Heck et al., 2014), segmentation approach is rarely used to explore the different patterns of Vietnamese' food risk evaluation.

This paper aims to analyse consumers' evaluation of food risk and their response to the perceived risk. We apply the mixed method approach that integrates quantitative and qualitative data. Using cluster analysis on survey data, we identify distinct consumer segments concerning their food risk assessment. We then investigate how such segments are characterised in terms of trust level, risk rating of hazards and response to risk. Group discussions complement the survey results by further investigating consumer feeling of food safety, the people they trust and their risk relievers for food bought from wet markets. The paper provides empirical evidence on consumer perception of food risk and risk-reducing strategies to support the risk communication in Vietnam. 
JABES

28,2

88

The paper is structured as follows: the next section presents materials and method, section 3 focusses on results and discussion and the last section concludes.

\section{Materials and method}

\subsection{Research design and study site}

This study applies the explanatory sequential mixed method that involves two phases in data collection. The quantitative phase is conducted first, followed by the qualitative phase that helps explain quantitative results (Creswell, 2013). Following this procedure, we carried out a consumer survey from February to April 2017. The survey was to capture data on food safety worry, risk rating of common foods, trust in the government and food industry, perception of hazards and response to food safety risk. Group discussions were facilitated in the late of May 2017 and guided by initial survey results. The survey data initially revealed a very high level of food safety concerns, a distrust in institutions and reliance on wet markets when shopping for food. Follow-up group discussions then explored consumer feeling about food risk, whom they place the trust in and their risk-reducing behaviours in wet market settings. Since risk perception is multidimensional and complex (Slovic, 2016), the integration of both quantitative and qualitative data would allow the exploration of this concept in more depth.

The study site of this research is Greater Hanoi. The city boundary was expanded in 2008 by merging Old Hanoi with former Ha Tay province, Me Linh district of Vinh Phuc province and four communes of Hoa Binh province. By 2017, Greater Hanoi had 12 urban, 17 rural districts and 1 town with a total population of $7.654 \mathrm{~m}$, of which $50.8 \%$ are rural people [1]. Having both rural and urban residents, Hanoi offers a complex mix of heterogeneous consumers, who are ideally suited for this research. A high level of economic development alongside food safety concerns in Hanoi would enable an interesting analysis of consumer self-evaluation of food safety risk and their risk relievers.

\subsection{Data collection}

2.2.1 Consumer survey. We selected four urban and three rural districts that have different social, economic development and geographical characteristics to conduct the survey (Table 1).

Hai Ba Trung, Thanh Xuan, Long Bien and Ha Dong are representative for the urban area of Hanoi. Hai Ba Trung is located right in the central of Hanoi with a long history of development. Thanh Xuan and Long Bien were formed later than Hai Ba Trung and a little further away from Hanoi centre. Ha Dong used to be a rural area before it was upgraded to an urban district in 2009.

At the time the survey was conducted, Chuong My, Dong Anh and Gia Lam were typical rural districts of Hanoi. Chuong My has become a district of Hanoi since 2008 while Dong Anh has been an iconic part of Hanoi from 1901. Gia Lam was experiencing a rapid urbanisation process. It has not only rural villages, where the majority of the population is engaging in farming, but also small towns with supermarkets, shopping centres and residential blocks.

Table 1.

Description of the study area and the number of observations by district

\begin{tabular}{|c|c|c|c|c|c|c|c|}
\hline & $\begin{array}{l}\text { Chuong } \\
\text { My }\end{array}$ & $\begin{array}{l}\text { Dong } \\
\text { Anh }\end{array}$ & $\begin{array}{l}\text { Gia } \\
\text { Lam }\end{array}$ & Ha Dong & $\begin{array}{l}\text { Long } \\
\text { Bien }\end{array}$ & $\begin{array}{l}\text { Thanh } \\
\text { Xuan }\end{array}$ & $\begin{array}{l}\text { Hai Ba } \\
\text { Trung }\end{array}$ \\
\hline Location & South East & North & West & $\begin{array}{l}\text { South } \\
\text { East }\end{array}$ & West & South East & Centre \\
\hline Region & Rural & Rural & Rural & Urban & Urban & Urban & Urban \\
\hline $\begin{array}{l}\text { Foundation } \\
\text { year }\end{array}$ & 2008 & 1901 & 1954 & 2009 & 2003 & 1996 & 1961 \\
\hline
\end{tabular}


Thus, Gia Lam can be considered as a semi-urban district though; in fact, it is administratively classified as a rural district.

Quota sampling (Kothari, 2004) was employed with a predetermined number of respondents to be selected in each chosen district. Target respondents were at least 18 years old and the main meal planner of households. According to Lin (1995), they play the role of a family's gatekeeper, who is responsible for selecting and determining the content, preparation and consumption of food in the household.

In total, 498 respondents (230 rural and 268 urban residents) were surveyed with valid questionnaires being ready for data analysis. This sample size is sufficient to perform a cluster analysis used in this paper. According to Kodinariya and Makwana (2013), an acceptable rule for cluster sample size is $5 \times 2^{k,}$ where $k$ is the number of variables. In this study, with six variables included in cluster analysis, the minimum sample size is 320 respondents, which is far below our actual sample size of 498 .

2.2.2 Demographic profile of the surveyed respondents and households. The majority of the respondents were female, as shopping and cooking are mainly women's responsibility in Vietnam (Table 2). Selected respondents were relatively young, with the mean age of 42 . Since Hanoi is one of the education centres of the country, the respondent's education level was quite high; about half of them have a university degree. Respondent's average monthly income was $7.5 \mathrm{~m}$ VND (US\$ 333). Noticeably, nearly $60 \%$ of the families had their homegrown vegetables.

2.2.3 Focus group discussions. Three group discussions were implemented during May 2017. Each group had eight participants who had been previously engaged in the survey. The survey at first revealed consumer's evaluation of food safety, their distrust in some institutions and their reliance on wet markets. Follow-up group discussions then explored emotional interpretations of food safety, whom consumers placed their trust in, and strategies to reduce the perceived risk associated with food sold in wet markets.

\subsection{Variable measurement and data analysis}

Since food risk perception is linked with trust and emotion, previous studies have measured risk perception by either the mean score of perceived risk or level of worry (Liu et al., 2014). Food risk perception, in turn, has been further used to reflect trust in food safety (Poppe and Kjærnes, 2003), pessimism or confidence in food (De Jonge et al., 2008a). Complementing previous literature, food risk perception in this study is constructed by not only the risk perceived of several common food groups but also food safety anxiety. This captures the complexity of consumer evaluation of food risk in a developing country context.

For the survey data, we used $K$ mean cluster analysis to segment respondents. $K$ mean has been proven to be a simple, fast and effective clustering technique (Kodinariya and Makwana, 2013). We used six segmentation variables that comprise risk rating of five food groups (vegetables, fruit, meat, egg, fish) and food safety worry level. All of these variables were measured by a ten-point Likert scale. We chose the number of clusters by Silhouette value (Kodinariya and Makwana, 2013). This value, which lies between -1 and +1 , measures the similarity of a data point to its cluster. There were different options for the number of clusters to be chosen, ranging from 2 to 10. We calculated the mean Silhouette score for each option and selected the four-cluster option that has the highest Silhouette score (0.53).

$K$ mean analysis shows that all of the segmentation variables were effective in explaining the differences among four chosen clusters $(p<0.01, F$ values in the range of 121-268). We then employed either $\lambda^{2}$ test or ANOVA, coupled with post hoc Tukey test to examine whether there are differences in demographics, trust in institutions, risk characteristics of hazards and response to the perceived food risk across segments. Since 


\section{JABES}

28,2

Features
Number of elderlies in the household
0
$1-2$
$\geq 3$

$90 \quad$ Number of children

0

$1-2$

$\geq 3$

Frequency

$\%$

$\begin{array}{rr}314 & 63.1 \\ 182 & 36.5 \\ 2 & 0.4 \\ & \\ 122 & 24.5 \\ 351 & 70.5 \\ 25 & 5.0\end{array}$

Household size

1-2

6.0

$3-4$

55.4

$\geq 5$

38.6

Household monthly expenditure (Million VND)

$<5$

From 5 to less than 10

From 10 to less than 15

From 15 to less than 20

$\geq 20$

Growing vegetables

Respondents' gender

Female

Respondents' education

No schooling

$8+1.6$

Primary school to vocational school

University and postgraduate

Respondent's age

$\leq 29$

From 30 to less than 39

Table 2.

Background

From 40 to less than 49

From 50 to less than 59

Note(s): $23,000 \mathrm{VND}=1$ USD

trust is multidimensional (de Jonge et al., 2008b) and varies across stakeholders (Chen, 2013), this variable was measured by personal trust in the government, farmers and retailers at wet markets. Risk characteristics of hazards include perceived control and self-reported consequence of pesticides, bacterial and heavy metals, using the scale adapted from Yeung and Morris (2006). We considered three responses to risk that are seeking food safety information, purchasing from supermarkets and growing own food. Food safety information seeking was measured by the frequency that respondents gather information through television, social media, relatives and friends. These are the most favourable channels from which consumers acquire food safety information (Rutsaert et al., 2013a).

The focus group discussions were tape-recorded, transcribed and then analysed. Given the characteristics of the mixed method, the data from the survey and group discussions are integrated into the result and discussion section of this paper when applicable. 


\section{Results and discussions}

3.1 Food risk in consumers' eye

Food safety matters to most of the surveyed consumers despite many attempts to improve food safety in Hanoi such as the replacement of wet markets with supermarkets (WertheimHeck et al., 2015) and the introduction of "safe" vegetable programs (Van Hoi et al., 2009). We found that $96 \%$ of respondents hold a negative attitude towards the safety of currently consumed food. This comprises 24 and $72 \%$ of them evaluating the safety of the currently available food "a little bit worse" and "much worse" than the past, respectively (Table 3 ). Moreover, the percentage of respondents reporting "much worse" was not statistically significantly different between the rural and urban regions $\left(\lambda^{2}=7.678, p=0.104\right)$. This result suggests that the pessimism about current food safety was widespread in Hanoi though, according to World Bank (2016), there has been some improvement in nutrition and food diversity in the household food basket in recent years. It is evident that when the country shifted from food insecurity to food abundance, thanks to modernised agri-food system (Ehlert and Faltmann, 2019), safety has emerged as the most intimidating aspect of food in consumers' lens.

Since risk perception is related to feelings such as "fear" and "threat" (Slovic, 2016), group discussions further explored consumer's emotional interpretation of risks embedded in unsafe food. During the group discussions, words such as "worry" and "scare" were cited frequently by participants when being asked to express their opinions about food safety. These negative feelings were derived from the awareness of the fundamental role of food and the presence of various chemical contaminations. In line with McCarthy et al. (2006), respondents in our study believed that chemical hazards were uncontrollable. Because of this belief, food safety risk remained unavoidable in consumer's eyes. This study, together with many others, suggests that risk perception is a social and psychological construct, which is constituted by personal emotion (Slovic, 2010) and belief (Lee et al., 2005).

We are all worried (about food safety), right? But we all have to eat. (Urban group discussion)

Pesticide, preservatives, nitrates, growth hormone, etc. . too many hazardous things are in the food now. (Rural group discussion)

Group discussions revealed different attitudes towards food safety risk. Similar to Mitchell (1999), we found most of the consumers were risk-averse to food consumption. They strived to eliminate the perceived risk such as carefully checking food appearance when purchasing, cooking food properly and avoiding eating raw foods. Notably, some of them were extremely risk-averse to food choice. As risk attitude determines risk behaviour (Cho and Lee, 2006), their fear of food safety risk resulted in their decisive self-protection actions:

I am very worried. I do no't dare to buy food from wet markets because I am afraid the food there is unsafe and untraceable. So, I mainly grab the food from my mom in my hometown. (Urban group discussion)
Food risk in consumers' eye

\begin{tabular}{ccc}
\hline Whole sample $(n=498)$ & Rural $(n=230)$ & $\operatorname{Urban}(n=268)$ \\
\hline
\end{tabular}

The safety of the currently available food as compared to ten years ago

(1) Much better

(2) A little bit better

1.0

1.8

1.4

(3) The same

(4) A little bit worse

(5) Much worse
23.9

71.9

\section{9}

0.4

0.4

24.3

73.9
1.1

3.0

2.2

23.5

70.1
Table 3.

Percentage of respondents evaluating the safety of the currently available food 


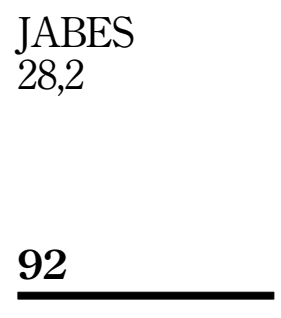

\begin{tabular}{lllll}
\hline Variables & $\begin{array}{l}\text { Segment 1 } \\
\text { Mean (SD) }\end{array}$ & $\begin{array}{l}\text { Segment 2 } \\
\text { Mean (SD) }\end{array}$ & $\begin{array}{l}\text { Segment 3 } \\
\text { Mean (SD) }\end{array}$ & $\begin{array}{l}\text { Segment 4 } \\
\text { Mean (SD) }\end{array}$ \\
\hline Vegetable risk & $5.28^{\mathrm{a}}(1.97)$ & $6.07^{\mathrm{b}}(1.26)$ & $7.73^{\mathrm{c}}(1.38)$ & $9.17^{\mathrm{d}}(0.98)$ \\
Fruit risk & $4.55^{\mathrm{a}}(1.62)$ & $5.28^{\mathrm{b}}(1.26)$ & $7.57^{\mathrm{c}}(1.49)$ & $9.18^{\mathrm{d}}(1.02)$ \\
Meat risk & $4.08^{\mathrm{a}}(1.45)$ & $7.01^{\mathrm{b}}(1.54)$ & $6.46^{\mathrm{c}}(1.69)$ & $9.14^{\mathrm{d}}(1.03)$ \\
Egg risk & $2.50^{\mathrm{a}}(1.11)$ & $4.54^{\mathrm{b}}(1.80)$ & $3.58^{\mathrm{c}}(1.55)$ & $6.70^{\mathrm{d}}(2.21)$ \\
Fish risk & $2.90^{\mathrm{a}}(1.25)$ & $5.93^{\mathrm{b}}(1.49)$ & $4.24^{\mathrm{d}}(1.34)$ & $7.95^{\mathrm{d}}(1.58)$ \\
Food safety worry & $5.20^{\mathrm{a}}(1.01)$ & $7.62^{\mathrm{b}}(1.85)$ & $8.08^{\mathrm{c}}(1.69)$ & $8.89^{\mathrm{d}}(1.52)$ \\
\hline
\end{tabular}

\begin{tabular}{lcccc}
\hline Segment name & $\begin{array}{c}\text { Mow-risk } \\
\text { perception }\end{array}$ & $\begin{array}{c}\text { Moder } \\
\text { perception }\end{array}$ & $\begin{array}{c}\text { High-risk } \\
\text { perception }\end{array}$ & $\begin{array}{c}\text { Very-high-risk } \\
\text { perception }\end{array}$ \\
\hline $\begin{array}{l}\text { Number of } \\
\text { respondents } \\
\% \text { of sample }\end{array}$ & 104 & 120 & 164 & 110 \\
Note & 20.88 & 24.09 & 32.94 & 22.09
\end{tabular}

Table 4.

Consumer segments based on selfevaluation of food risk

Note(s): ${ }^{\text {a, b, c, d }}$ Scores in one row with a different superscript are significantly different at $p<0.05$ using oneway ANOVA and post hoc Tukey test

\subsection{Consumer segments based on food risk evaluation}

Cluster analysis identifies four distinct consumer segments that differed in the subjective evaluation of food safety. As shown in Table 4, the mean scores of all variables were statistically significantly different across segments. The first segment, which occupied onefifth of the whole sample, was named "Low-Risk Perception". Consumers in this segment were least worried about food safety, and their risk perception of various food categories was also the lowest and below the neutral level, except for vegetables.

The "Moderate Risk Perception" segment had a quite high level of food safety worry (7.62 out of 10), and the risk perception of almost food products was above the neutral level, ranging from roughly 5 to 7 out of 10 . The "High-Risk Perception" was even worried more about food safety and viewed a considerable risk from vegetables and fruit $(7.73$ and 7.57 out of 10). Notably, the "Very High-Risk Perception" is at the extreme end. This group exhibits a very high level of food safety worry as well as risk perception from most common foods. Three segments comprising of Moderate, High and Very-High-Risk Perception accounted for $80 \%$ of the whole sample. This is evidence of the prevalence of the distrust in food in Vietnam that is also well documented in the previous literature (Van Hoi et al., 2009; Figuié et al., 2004).

Table 5.

Demographic characteristics across segments

\begin{tabular}{|c|c|c|c|c|}
\hline Variables & $\begin{array}{l}\text { Segment } 1 \text { (Low- } \\
\text { risk Perception) }\end{array}$ & $\begin{array}{l}\text { Segment } 2 \\
\text { (Moderate-risk } \\
\text { perception) }\end{array}$ & $\begin{array}{l}\text { Segment } 3 \text { (High- } \\
\text { risk perception) }\end{array}$ & $\begin{array}{l}\text { Segment } 4 \text { (Very- } \\
\text { high-risk } \\
\text { perception) }\end{array}$ \\
\hline Age & 43.24 (12.71) & 42.97 (13.19) & 41.62 (12.58) & 39.75 (11.68) \\
\hline $\begin{array}{l}\text { Individual income } \\
\text { (mil VND/month) }\end{array}$ & 6.99 (4.75) & $7.55(6.52)$ & $7.69(5.77)$ & 7.79 (6.02) \\
\hline $\begin{array}{l}\text { Female } \\
\text { respondents }\end{array}$ & $84.6 \%$ & $89.2 \%$ & $85.4 \%$ & $90.9 \%$ \\
\hline Having children* & $76.9 \%$ & $65.0 \%$ & $78.0 \%$ & $81.8 \%$ \\
\hline University degree* & $48.10 \%$ & $43.30 \%$ & $51.20 \%$ & $63.60 \%$ \\
\hline Living in urban* & $42.30 \%$ & $51.70 \%$ & $57.30 \%$ & $61.80 \%$ \\
\hline \multicolumn{5}{|c|}{$\begin{array}{l}\text { Note(s): Mean and standard deviation are shown for continuous variables (age, individual income) } \\
\% \text { is shown for dummy variables (female, having children, university degree, living in urban) } \\
\text { *group differences are statistically significant at } 5 \% \text { level, using } \lambda^{2} \text { test }\end{array}$} \\
\hline
\end{tabular}


Table 5 illustrates the demographic profile of four consumer segments. Age, income and gender did not differ across segments. However, the presence of children in the family, education and region were statistically significantly different among segments at $5 \%$ level, using $\lambda^{2}$ test. Table 5 shows that the percentage of respondents having children was larger in High and Very High Perceived Risk segments. This is because children are known to be more vulnerable to food-related illnesses. Food safety, therefore, is more important for main food shoppers who have children in the household (Lin, 1995).

The percentage of respondents having a university degree was also higher in the High Pessimism and Very-High-Risk Perception groups. Perhaps, people with higher education level are more likely to search for food risk information (Yang et al., 2020) and therefore, might acquire more negative news relating to food safety. This thereby might translate into higher risk perception and food safety anxieties. Noticeably, the proportion of urban residents increased with perception of food risk. Very-High-Risk Perception group had $61 \%$ of urban respondents while the corresponding figure for Low-Risk Perception was only $42 \%$. Consistent with Liu and Ma (2016), our survey indicates that urban people were likely to perceive a higher food safety risk and feel more distrustful of food safety. This might be due to more frequent access to food safety incidents in urban regions (Shi, 2001). There is evidence of the failure of risk communication in Vietnam. Media attention on the negative aspects of food has heightened food safety worries (Nguyen-Viet et al., 2017). With better access to information, urban consumers might acquire more negative news about food safety, resulting in higher risk perception and pessimism.

\subsection{Drivers of risk perception across identified segments}

3.3.1 Institutional trust. Table 6 provides statistics of trust variables of the whole sample and each consumer segment. For the whole surveyed sample, trust was very low, especially trust in food traders (mean score of 2.42 out of 10 ).

Noticeably, Low-Risk Perception segment holds the highest level of trust in all institutions of consideration. ANOVA and post hoc Tukey test confirm that all trust items of this group were statistically significantly different from those of the remaining groups. In general, trust in institutions was lower in the three segments that perceived a higher food risk (Moderate, High, Very-High-Risk Perception). This result is consistent with well-documented evidence on the inversive relationship between trust in the government and food industry and consumer perception of food risk (de Jonge et al., 2008b).

The finding from group discussions complemented the survey results. Very often, group discussion participants expressed that they did not hold the trust in any organisations or any people. In particular, the distrust in farmers and food traders led to a perception that food in the wet market was unsafe.

\begin{tabular}{lccccc}
\hline & $\begin{array}{c}\text { Whole } \\
\text { sample } \\
\text { Mean (SD) }\end{array}$ & $\begin{array}{c}\text { Low-risk } \\
\text { perception } \\
\text { Mean (SD) }\end{array}$ & $\begin{array}{c}\text { Moderate-risk } \\
\text { perception } \\
\text { Mean (SD) }\end{array}$ & $\begin{array}{c}\text { High-risk } \\
\text { perception } \\
\text { Mean (SD) }\end{array}$ & $\begin{array}{c}\text { Very-high-risk } \\
\text { perception } \\
\text { Mean (SD) }\end{array}$ \\
\hline $\begin{array}{l}\text { Trust in the } \\
\text { government }\end{array}$ & $4.11(2.95)$ & $5.35^{\mathrm{a}}(3.15)$ & $4.14^{\mathrm{b}}(2.84)$ & $3.78^{\mathrm{b}}(2.74)$ & $3.42^{\mathrm{b}}(2.86)$ \\
$\begin{array}{l}\text { Trust in farmers } \\
\text { Trust in food traders }\end{array}$ & $2.77(2.18)$ & $3.14^{\mathrm{a}}(2.31)$ & $2.63^{\mathrm{b}}(2.01)$ & $2.75^{\mathrm{b}}(2.28)$ & $2.63^{\mathrm{b}}(2.08)$ \\
& $2.42(1.85)$ & $2.99^{\mathrm{a}}(2.10)$ & $2.18^{\mathrm{b}}(1.64)$ & $2.39^{\mathrm{b}}(1.94)$ & $2.22^{\mathrm{b}}(1.60)$
\end{tabular}
at wet markets

Note(s): ${ }^{\text {a, b }}$ Scores in one row with a different superscript are significantly different at $p<0.05$ using one-way ANOVA and post hoc Tukey test. Trust was measured by ten-point Likert scale, ranging from 1 (do no't trust at all) to 10 (completely trust)

Food risk in consumers' eye
Table 6.

Institutional trust by segment 
JABES

28,2

94

Buying untraceable food in the market is very dangerous. Sellers said their food is safe although farmers just have sprayed pesticides and grew regulators. All of them are profit-oriented. (Urban group discussion)

The group discussions then explored who gained the trust of consumers. It was evident that consumers trusted themselves the most. Like Wertheim-Heck et al. (2014), we found that when shopping for food in wet markets, consumers placed their trust in local farmers and regular vendors whom they had established a relationship with for a long time.

I can evaluate food safety through my cooking experience. I just trust in myself. Government, supermarkets, farmers, I do not trust any of them. (Rural group discussion)

I live in Gia Lam but have to shop weekly for fresh food at Hang Be market (at Hanoi center). I only buy from my regular vendors who I have known for a long time since I was a child. I feel the food there is more delicious and safer. (Rural group discussion)

I only buy vegetables from local people who sell vegetables in a small quantity. These people grow vegetables for their family eating and just sell oversupply amount. Because they grow vegetables for their family need, their vegetables are safe. (Urban group discussion)

3.3.2 Risk characteristics of food hazards. In general, respondents across segments believed that they had a very low level of control over all selected hazards (Table 7). Most of the mean scores of "subjective control" items across hazards for all segments were just under the neutral level. In contrast, the mean scores of "consequences" items across all the hazards were very high, ranging from roughly 7.0 to 9.0, suggesting that respondents view these hazards highly dangerous. In line with Kher et al. (2013), our research results imply that consumers are likely to perceive the danger or the severity of food hazards when they feel the lack of control over hazards.

Comparing across segments, Low-Risk Perception was characterised by the highest subjective control and the lowest self-reported consequences of hazards. In contrast, VeryHigh-Risk Perception felt very little control over hazards and rated all hazards extremely dangerous. Low level of subjective control over hazards led to the perception that food hazards are dangerous. In general, consumers who are more worried about food safety were likely to perceive a greater danger from food hazards. In line with the psychometric paradigm, we found the relationship between risk perception and perceived severity, one of the risk characteristics of hazards.

\begin{tabular}{lcccc}
\hline & Low-risk & Moderate-risk & High-risk & Very-high-risk \\
& perception & perception & perception & perception \\
Variables & Mean (SD) & Mean (SD) & Mean (SD) & Mean (SD) \\
\hline
\end{tabular}

Subjective control over

\begin{tabular}{|c|c|c|c|c|}
\hline & & & & \\
\hline Pesticide & $4.22^{\mathrm{a}}(2.23)$ & $3.28^{\mathrm{b}}(2.18)$ & $3.46^{\mathrm{b}}(2.13)$ & $2.90^{\mathrm{b}}(2.09)$ \\
\hline Bacteria & $5.25^{\mathrm{a}}(2.49)$ & $4.30^{\mathrm{b}}(2.42)$ & $5.35^{\mathrm{a}}(2.59)$ & $4.71^{\mathrm{a}}(2.62)$ \\
\hline (3) Heavy metal & $3.43^{\mathrm{a}}(2.09)$ & $2.60^{\mathrm{b}}(1.83)$ & $2.84^{\mathrm{b}}(1.96)$ & $2.66^{\mathrm{b}}(2.13)$ \\
\hline
\end{tabular}

Self-reported consequences of

\begin{tabular}{|c|c|c|c|c|c|}
\hline (1) & Pesticide & $7.50^{\mathrm{a}}(2.35)$ & $7.97^{\mathrm{ab}}(1.87)$ & $8.20^{\mathrm{b}}(1.91)$ & $9.14^{\mathrm{c}}(1.40)$ \\
\hline (2) & Bacteria & $6.63^{\mathrm{a}}(2.30)$ & $7.25^{\mathrm{b}}(1.97)$ & $7.23^{\mathrm{b}}(2.08)$ & $8.00^{\mathrm{c}}(2.32)$ \\
\hline (3) & Heavy metal & $7.13^{\mathrm{a}}(2.30)$ & $8.01^{\mathrm{b}}(1.78)$ & $7.75^{\mathrm{b}}(2.05)$ & $8.78^{\mathrm{c}}(1.96)$ \\
\hline
\end{tabular}

Table 7.

Perception of food hazards by consumer segments
Note(s): ${ }^{\text {a, b,c }}$ Scores in one row with a different superscript are significantly different at $p<0.05$ using one-way ANOVA and post hoc Tukey test. "Control" and "Consequence" items were measured by ten-point Likert scale. For Control items, 1 denotes "completely uncontrollable" while 10 presents "completely controllable." For Consequence items, 1 means "not dangerous at all" and 10 represents "extremely dangerous" 
We conduct a correlation analysis to reveal respondents' actual knowledge of hazards. The analysis shows that self-reported consequences across hazards were significantly and highly correlated (Table 8). Most of the correlation coefficients are between 0.4 and 0.7 . This highly correlated data set suggests that consumers were unable to distinguish different hazards. Rimal et al. (2001) also reported a high correlation in consumer perception of seven hazards including pesticide, veterinary drug, growth hormone, food additives, bacteria, irradiation and naturally occurring toxin. Agreeing with previous studies (Verbeke $e t$ al., 2007; Rimal et al., 2001), this paper indicates that consumers' knowledge of food hazards is limited.

\subsection{Response to the perceived food risk}

Table 9 shows the risk-reducing behaviour of each consumer segment. Ample evidence illustrates that seeking food safety information is one of the key responses of consumers when perceiving a risk embedded in food. Consumers seek advice from friends and relatives who are trustworthy to select safe food (Yeung and Yee, 2002). They may also use various media sources (television, the Internet and print) that do not require an intensive search (Liu et al., 2014). In this study, the frequency of food safety information seeking from television (TV) was not different among segments. This is because TV is the most common mass media in rural as well as urban regions in Hanoi. But there is a divide between "Very High-Risk Perception" and the remaining segments in searching food safety information from the social media and relatives. ANOVA and post hoc Tukey test confirm that Very-High-Risk Perception group was more likely to seek food safety information from these two sources as compared to the remaining groups. This result is quite similar to Yang et al. (2020), who

\begin{tabular}{lccc}
\hline Perceived consequence of & Pesticide & Bacteria & Heavy metal \\
\hline Pesticide & 1.00 & $0.63^{* * *}$ & $0.64^{* * *}$ \\
Bacteria & $0.63^{* *}$ & 1.00 & $0.70^{* *}$ \\
Heavy metal & $0.64^{* *}$ & $0.70^{* *}$ & 1.00 \\
Note(s): ${ }^{* *}$ significant at 1\% level (two-tailed) & &
\end{tabular}

Food risk in consumers' eye

\begin{tabular}{lcccc}
\hline Variables & $\begin{array}{c}\text { Low-risk } \\
\text { perception } \\
\text { Mean (SD) }\end{array}$ & $\begin{array}{c}\text { Moderate-risk } \\
\text { perception } \\
\text { Mean (SD) }\end{array}$ & $\begin{array}{c}\text { High-risk } \\
\text { perception } \\
\text { Mean (SD) }\end{array}$ & $\begin{array}{c}\text { Very-high-risk } \\
\text { perception } \\
\text { Mean (SD) }\end{array}$ \\
\hline $\begin{array}{l}\text { Frequency of food safety information seeking from } \\
\text { (1) TV }\end{array}$ & $3.82(0.80)$ & $3.83(0.80)$ & $3.98(0.81)$ & $4.05(0.90)$ \\
$\begin{array}{l}\text { (2) Social media } \\
\text { (3) Relatives and peers }\end{array}$ & $3.14^{\mathrm{a}}(1.29)$ & $3.13^{\mathrm{a}}(1.17)$ & $3.34^{\mathrm{a}}(1.27)$ & $3.78^{\mathrm{b}}(1.29)$ \\
\% of respondents purchasing & $3.60^{\mathrm{a}}(0.84)$ & $3.56^{\mathrm{a}}(0.94)$ & $3.60^{\mathrm{a}}(0.96)$ & $4.02^{\mathrm{b}}(0.90)$ \\
food from supermarkets* & 37.5 & 36.7 & 37.2 & 49.1 \\
$\%$ of respondent self- & & & & 54.9 \\
provisioning of food*
\end{tabular}

Note(s): ${ }^{\text {a, b }}$ Scores in one row with a different superscript are significantly different at $p<0.05$ using one-way ANOVA and post hoc Tukey test

*group differences are statistically significant at $5 \%$ level, using $\lambda^{2}$ test

1: variables are measured by five-point Likert scale from 1 (rarely) to 5 (usually)

Table 8.

Correlation matrix of perceivedconsequence items
Table 9.

Consumers' responses to food safety risk 
JABES

28,2

96 reported that intention to seek food safety information via social media was higher for consumer groups who hold a high-risk perception in China.

Purchasing food from supermarkets is another consumers' response to reduce the perceived food risk. This is because of the common belief of Vietnamese consumers that foods sold in supermarkets are safe and guaranteed, compared to those in wet markets (Figuié and Moustier, 2009). As shown in Table 9, Very-High-Risk Perception had the highest percentage of consumers who purchased food from supermarkets $(49 \%)$. The corresponding figures were quite similar in the remaining segments, ranging from 36 to $37 \%$. Seeking food safety information more frequently and engaging more in supermarket purchase, Very-High-Risk Perception seems to be the most risk-averse group.

Growing their own food is another strategy employed by consumers to reduce the potential health risk from marketed food. The percentage of growing-own-food consumers tend to be similar between Low and Moderate-Risk Perception and between High and VeryHigh-Risk Perception with the former having a higher percentage. Group discussions show all participants highly evaluated home-grown food because of their safety attribute. This result is in agreement with Green $e t$ al. (2003), who found that home-made food was the most preferable. Referring back to the survey result, we argue that due to the awareness about the safety of home-grown food, Low and Moderate-Risk Perception groups that engaged more in self-provision of food have reduced worry about food safety. In contrast, the absence of home grown foods has increased food safety concerns and resulted in high and very high risk perception in the remaining segments.

Our survey found that since home-grown food contributed only $27 \%$ of the total food consumption of the family, the majority of households surveyed still relied on marketed food. In wet markets, foods directly bought from local people were consumers' preference. There was a common perception that food from the rural area and/or local people was safer. This finding is comparable to that of Gong and Jackson (2012), who found rural region was highly acknowledged because of its capacity to produce safer food. Our result challenges the traditional notion that rural regions are backward as compared to urban areas. While ruralurban gaps in economic and social development remain wide in Vietnam, thanks to this capacity, the position of the rural region had been reversed.

I just buy vegetables from my neighbours in my home village though the price might be triple than that in the market here. I just trust in the food of rural people. Rural food is safer, fresher and more delicious. (The first group discussion)

I just buy (food) from 5 people at Dang Xa market. They are local people, just selling a little bit after supplying enough for their family. (The second group discussion)

\section{Conclusions and policy implications}

Using the mixed method approach, this paper found that food scares were widely spread in Hanoi. To deduce food scares, the government should step up efforts towards ensuring food safety. Providing incentives for behavioural changes such as technical supports and quality certificates for those who are applying good safety practices might be a solution. It should be noted that the lack of motivations to produce safe food has led to the shortfall of ethical behaviour among actors in the food chains, a core problem of food safety in Vietnam (NguyenViet et al., 2017).

Based on risk perception of common food and level of food safety worry, cluster analysis distinguished four groups of consumers: low, moderate, high and very-high-risk perception. $80 \%$ of survey respondents belonged to the last three segments. This is another evidence of the prevalence of pessimism in food safety among Hanoi consumers. Geographical features characterised identified segments. Living in urban regions was associated with a higher level 
of risk perception and worry. Better access to information in urban regions and the failure of risk communication might be potential reasons for this result. To address the heightened risk perception, three principles in risk communication, namely honesty, openness and transparency (Seeger, 2006), should be applied in communicating food risk to urban dwellers.

Trust in the government and actors in the food chain was very low among three segments that perceived a higher food risk (Moderate, High, Very-High-Risk Perception). Group discussion further revealed that respondents trusted in food produced or cooked by themselves the most. Consumers also placed their trust in regular vendors or local farmers in wet markets whom they have known for a long time. Enhancing consumers' confidence, particularly for those who are more pessimistic about food requires an improvement of institutional trust. According to de Jonge et al. (2008b), to gain consumer trust, the government and actors in food chains need to show a good care of public well-being, the competence to control food safety and the honesty about the safety of food.

Subjective control over hazards was found to be critically low, particularly in three groups: moderate, high and very-high-risk perception. Moreover, there was an association between food risk perception and self-reported consequences of hazards. These findings imply that reducing the perceived consequences and improving subjective control over hazards can address food safety worries. Since actual knowledge of food hazards is low, education on food hazards for consumers is a solution to improve their subjective control over hazards and confidence in food safety.

Response to food risk perception differed across segments. The segment with the highestrisk perception was also the most risk-averse. This segment put more effort into seeking food safety information via the Internet and personal channels and engaged more in supermarket purchase. To reduce food safety worries of this segment, we suggest that the use of social media to promote food safety education should be enhanced. This online platform has been proven to be effective in disseminating food safety information (Rutsaert et al., 2013b). Low and moderate-risk perception groups tend to participate more in self-supply of food, and this participation reduced their food safety concern. Such consumer reaction reflects a market failure in supplying safe food and implies potential economic losses of domestic food production. Attempts to correct this failure will improve the welfare of not only consumers but also other actors in the food chain. Besides, there was increasing interest in sourcing safe food from rural regions and local people. Preference for local food is evidence that the rural region is now widely acknowledged because of its ability to supply safe food. This suggests an opportunity for local farmers to expand the production of safe food to serve their wealthy urban customers.

\section{Notes}

1. Data from Hanoi People Committee http://thanglong.chinhphu.vn

\section{References}

Chen, W. (2013), "The effects of different types of trust on consumer perceptions of food safety: an empirical study of consumers in Beijing Municipality, China”, China Agricultural Economic Review, Vol. 5, pp. 43-65.

Cho, J. and Lee, J. (2006), "An integrated model of risk and risk-reducing strategies", Journal of Business Research, Vol. 59, pp. 112-120.

Creswell, J.W. (2013), Research Design: Qualitative, Quantitative, and Mixed Methods Approaches, Sage publications, Los Angeles.

De Jonge, J., Van Trijp, H., Goddard, E. and Frewer, L. (2008a), "Consumer confidence in the safety of food in Canada and The Netherlands: the validation of a generic framework", Food Quality and Preference, Vol. 19, pp. 439-451. 
JABES 28,2

de Jonge, J., Van Trijp, J., van der Lans, I.A., Renes, R.J. and Frewer, L.J. (2008b), "How trust in institutions and organizations builds general consumer confidence in the safety of food: a decomposition of effects", Appetite, Vol. 51, pp. 311-317.

Ehlert, J. and Faltmann, N.K. (2019), Food Anxiety in Globalising Vietnam, Palgrave Macmillan, Singapore.

Figuié, M. and Moustier, P. (2009), "Market appeal in an emerging economy: supermarkets and poor consumers in Vietnam", Food Policy, Vol. 34, pp. 210-217.

Figuié, M., Bricas, N., Thanh, V.P.N., Truyen, N.D. and de l'Alimentation, E.S.E. (2004), "Hanoi consumers' point of view regarding food safety risks: an approach in terms of social representation”, Vietnam Social Sciences, Vol. 3, pp. 63-72.

Gong, Q. and Jackson, P. (2012), "Consuming anxiety? Parenting practices in China after the infant formula scandal”, Food, Culture and Society, Vol. 15, pp. 557-578.

Green, J., Draper, A. and Dowler, E. (2003), "Short cuts to safety: risk and'rules of thumb'in accounts of food choice", Health, Risk and Society, Vol. 5, pp. 33-52.

Grunert, K.G. (2005), "Food quality and safety: consumer perception and demand", European Review of Agricultural Economics, Vol. 32, pp. 369-391.

Ha, T.M., Shakur, S. and Do, K.H.P. (2020), "Linkages among food safety risk perception, trust and information: evidence from Hanoi consumers", Food Control, Vol. 110, p. 106965.

Kennedy, J., Worosz, M., Todd, E.C. and Lapinski, M.K. (2008), "Segmentation of US consumers based on food safety attitudes", British Food Journal, Vol. 110, pp. 691-705.

Kher, S.V., De Jonge, J., Wentholt, M.T., Deliza, R., de Andrade, J.C., Cnossen, H.J., Luijckx, N.B.L. and Frewer, L.J. (2013), "Consumer perceptions of risks of chemical and microbiological contaminants associated with food chains: a cross-national study", International Journal of Consumer Studies, Vol. 37, pp. 73-83.

Kodinariya, T.M. and Makwana, P.R. (2013), "Review on determining number of cluster in $K$-means clustering", International Journal, Vol. 1, pp. 90-95.

Kothari, C.R. (2004), Research Methodology: Methods and Techniques, 2nd ed., New Age International, New Delhi, (Chapter 4).

Lee, C.-J.E., Lemyre, L., Mercier, P., Bouchard, L. and Krewski, D. (2005), "Beyond the hazard: the role of beliefs in health risk perception", Human and Ecological Risk Assessment, Vol. 11, pp. 1111-1126.

Li, J.H. and Ko, Y.C. (2012), "Plasticizer incident and its health effects in Taiwan", The Kaohsiung journal of medical sciences, Vol. 28, pp. S17-S21.

Lin, C.-T.J. (1995), "Demographic and socioeconomic influences on the importance of food safety in food shopping", Agricultural and Resource Economics Review, Vol. 24, pp. 190-198.

Liu, P. and Ma, L. (2016), "Food scandals, media exposure, and citizens' safety concerns: a multilevel analysis across Chinese cities", Food Policy, Vol. 63, pp. 102-111.

Liu, R., Pieniak, Z. and Verbeke, W. (2014), "Food-related hazards in China: consumers' perceptions of risk and trust in information sources", Food Control, Vol. 46, pp. 291-298.

McCarthy, M., Brennan, M., Ritson, C. and de Boer, M. (2006), "Food hazard characteristics and risk reduction behaviour: the view of consumers on the island of Ireland", British Food Journal, Vol. 108, pp. 875-891.

Mitchell, V.-W. (1999), “Consumer perceived risk: conceptualisations and models”, European Journal of Marketing, Vol. 33, pp. 163-195.

Nguyen-Viet, H., Tuyet-Hanh, T.T., Unger, F., Dang-Xuan, S. and Grace, D. (2017), "Food safety in Vietnam: where we are at and what we can learn from international experiences", Infectious diseases of poverty, Vol. 6, p. 39.

Poppe, C. and Kjærnes, U. (2003), Trust in Food in Europe: A Comparative Analysis, National Institute for Consumer Research, Oslo. 
Premanandh, J. (2013), "Horse meat scandal-A wake-up call for regulatory authorities", Food Control, Vol. 34, pp. 568-569.

Rimal, A., Fletcher, S.M., McWatters, K., Misra, S.K. and Deodhar, S. (2001), "Perception of food safety and changes in food consumption habits: a consumer analysis", International Journal of Consumer Studies, Vol. 25, pp. 43-52.

Rutsaert, P., Pieniak, Z., Regan, Á., McConnon, Á. and Verbeke, W. (2013a), "Consumer interest in receiving information through social media about the risks of pesticide residues", Food Control, Vol. 34, pp. 386-392.

Rutsaert, P., Regan, Á., Pieniak, Z., McConnon, Á., Moss, A., Wall, P. and Verbeke, W. (2013b), "The use of social media in food risk and benefit communication", Trends in Food Science and Technology, Vol. 30, pp. 84-91.

Sarter, S., Ha, H.P. and Anh, T.K. (2012), "Current situation of food safety in Vietnam", The 1st FOODSEG Symposium, Berlin, Germany, pp. 21-22.

Seeger, M.W. (2006), "Best practices in crisis communication: an expert panel process", Journal of Applied Communication Research, Vol. 34, pp. 232-244.

Shi, T. (2001), "Cultural values and political trust: a comparison of the People's Republic of China and Taiwan", Comparative Politics, pp. 401-419.

Siegrist, M. (2000), "The influence of trust and perceptions of risks and benefits on the acceptance of gene technology”, Risk Analysis, Vol. 20, pp. 195-204.

Slovic, P. (1987), "Perception of risk", Science, Vol. 236, pp. 280-285.

Slovic, P. (Ed.) (2010), The Feeling of Risk: New Perspectives on Risk Perception, Routledge, London, (Chapter 1).

Slovic, P. (Ed.) (2016), The Perception of Risk, Taylor and Francis, New York, NY, (Chapter 25).

Van Hoi, P., Mol, A.P. and Oosterveer, P.J. (2009), "Market governance for safe food in developing countries: the case of low-pesticide vegetables in Vietnam", Journal of Environmental Management, Vol. 91, pp. 380-388.

Verbeke, W., Frewer, L.J., Scholderer, J. and De Brabander, H.F. (2007), "Why consumers behave as they do with respect to food safety and risk information", Analytica Chimica Acta, Vol. 586, pp. 2-7.

Wertheim-Heck, S.C., Vellema, S. and Spaargaren, G. (2015), "Food safety and urban food markets in Vietnam: the need for flexible and customized retail modernization policies", Food Policy, Vol. 54, pp. 95-106.

Wertheim-Heck, S.C., Vellema, S. and Spaargaren, G. (2014), "Constrained consumer practices and food safety concerns in Hanoi", International Journal of Consumer Studies, Vol. 38, pp. 326-336.

WHO (2015), WHO Estimates of the Global Burden of Foodborne Diseases: Foodborne Disease Burden Epidemiology Reference Group 2007-2015, World Health Organization.

World Bank (2016), Transforming Vietnamese Agriculture: Gaining More from Less, Hanoi, available at: http://documents.worldbank.org/curated/en/116761474894023632/pdf/108510-WPPUBLIC.pdf.

Yang, S.-C., Lin, C.-H., Aljuffali, I.A. and Fang, J.-Y. (2017), "Current pathogenic Escherichia coli foodborne outbreak cases and therapy development", Archives of Microbiology, Vol. 199, pp. 811-825.

Yang, Z., Paudel, K.P., Wen, X., Sun, S. and Wang, Y. (2020), "Food safety risk information-seeking intention of WeChat users in China", International Journal of Environmental Research and Public Health, Vol. 17, p. 2376.

Yeung, R.M. and Morris, J. (2006), "An empirical study of the impact of consumer perceived risk on purchase likelihood: a modelling approach”, International Journal of Consumer Studies, Vol. 30, pp. 294-305.

Food risk in consumers' eye 
JABES

28,2

Yeung, R.M. and Yee, W.M. (2002), "Multi-dimensional analysis of consumer-perceived risk in chicken meat", Nutrition and Food Science, Vol. 32, pp. 219-226.

\section{Corresponding author}

Thanh Mai Ha can be contacted at: t.ha@massey.ac.nz

For instructions on how to order reprints of this article, please visit our website: www.emeraldgrouppublishing.com/licensing/reprints.htm Or contact us for further details: permissions@emeraldinsight.com 